\title{
Children's Voices in Australian School Age Care: What do They Think About Afterschool Care?
}

\author{
Kym Simoncini, Jennifer Cartmel, and Amy Young
}

\begin{abstract}
Participation in after school care in Australia has more than doubled since the 1980s with hundreds of thousands of children attending every day. Historically this form of care has been regarded as a service for parents rather than an opportunity for children. There is a paucity of Australian research for school age care (SAC). This study investigated children's perceptions and experiences of afterschool care. 164 children in Prep/kindergarten to Year 7 across 14 services in Canberra and Logan participated in the research. Five questions were used to survey the children. Their responses supported the notion that SAC settings are important contexts of childhood and development. Afterschool care affords children opportunities to develop skills and competencies, make new friends as well as promoting and protecting play. Areas of health and safety, staffing, relationships with children were revealed as ways afterschool care could improve.
\end{abstract}

Keywords: school age care, afterschool care, out of school hours care, children's voices

\section{Introduction}

School age care (SAC) is the fastest growing sector of childcare services in Australia and has the greatest proportion of children attending services (DEEWR, 2013). SAC also referred to as outside school hours care includes before school care, afterschool care and vacation care and provides school-aged children (5-12 years) with supervised and planned recreational activities in a safe environment (DEEWR, 2011) while their parents are working or studying. The numbers of children attending SAC services has been steadily climbing since the mid 1990s and show no signs of declining. The number of children using approved outside school hours care in the 2012 September increased by 80,000 from September quarter 2004. The number of families using SAC has increased four-fold during the same time frame (DEEWR, 2013). SAC services are critical to the children and families who use them (Hand \& Baxter, 2013; Simoncini, Caltabiano \& Lasen, 2012; Winefield, Piteo, Kettler, Roberts, Taylor, Tuckey, ... et al., 2011). Despite the large and increasing numbers of children and families who access SAC, there is a paucity of research about SAC in Australia (Cartmel \& Grieshaber, 2014; Mullan, 2012; Winefield et al, 2011).

The purpose of this study was to investigate children's perceptions and experiences at after school care. Bronfenbrenner's Ecological Systems Theory (1979) or 
Bioecological model (1995) posits that children's development occurs within social, cultural and historical contexts. Children are viewed as active participants in their relationships and in creating their environments, and both biological dispositions and environmental forces are thought to shape development. The interactions between these relationships and environments explain differences in child development. According to Bronfenbrenner (1979) development is phenomenological, that is, what matters is how children perceive their environments rather than how they may exist objectively. Depending on family structure, proximity to other children, home resources as well as personality traits, children vary in how they perceive and experience SAC. For example an only child who has no children living in close proximity to their house may enjoy the contact with friends at afterschool care, while a ten-year old child may feel too old to attend afterschool care and wish to have more freedom. We hoped that illuminating children's experiences and perceptions of afterschool care might raise the profile of SAC as an important context for development rather than a service for parents. Using two diverse research sites we sought to explore children's perceptions and experiences of afterschool care and examine variables of age, gender, location and attendance patterns.

\section{Review of the Literature}

Afterschool care programs have been running in Australia since the 1900s (Brennan, 1999; Elliot, 1998; Finlason, 2004). Initially they began as recreational programs for children operating in community playgrounds. The programs later moved to community halls and school sites and were coordinated by arts or recreational organisations. These recreational programs continued until after the 1970s when the demand for services that provided "care" rather than recreation emerged (Moyle, Meyer, \& Evans, 1996). During the early 1980s there was a rapid expansion of SAC services as women's participation in the workforce increased (Brennan, 1996; Elliot, 1998; OECD, 2001). Since then there has been a shift of focus from children's needs to parents' needs (Brennan, 1994; Finlason, 2004). Today SAC services are intended to provide children with a place to engage in a range of play and leisure experiences that allow them to feel happy, safe and relaxed (DEEWR, 2011). Academic enrichment or remediation is not offered beyond children being able to complete their homework while at afterschool care.

The strategic direction of Australian SAC services and schools has been a topic of discussion, but of low priority (Arnold, 2002). The majority of SAC services are located on school sites; however, government policy makers and legislators view $\mathrm{SAC}$ as separate from the day-to-day operations of their venue hosts. One might consider SAC services as invisible additions to school sites (Cartmel, 2007). Despite being located on school sites there is great diversity in the provenance and organisational structures of SAC services. Providers of afterschool care include schools and/or their Parents and Citizens organisations, local councils, church bodies, long day centres, not-for-profit community groups and for-profit organisations. Fewer and fewer schools manage their own SAC service. 
SAC has a much lower profile than other types of childcare and school. SAC has been considered the "poor relative" in child care (Department of Health and Family Services, 1997) and the "Cinderella of services" (Gammage, 2003). Early childhood services are considered to offer both care and education for young children, whereas school age children are thought to be educated at school, and cared for at SAC until their parents collect them (Department of Family and Community Services (FaCS), 2005; Elliot, 1998). The perception that OSHC has limited operational hours has contributed to the low standing of this type of care (Cartmel, 2007). Over the course of the school years, the time spent in SAC has the potential to make up a sizable portion of children's lives and as such must influence their development. The continued use of "care" perpetuates the low opinion of SAC.

The development of Australian SAC services has been in tandem with the growth of services internationally in New Zealand, Britain, Europe, United States and Canada. A diverse range of services mushroomed in response to community need and prompted a growth of services. Services have reported some similar features to Australian SAC (Cartmel, 2007). The Nordic countries have a long history in SAC programs and research. SAC programs for the Nordic countries promote children's right to meaningful leisure time (Palsdottir, 2012). In the US, SAC is referred to as after school programs (ASP) - care has been replaced by program and immediately conjures another representation of children's time after school.

Traditionally in Australia SAC has not been regarded as making any instructional, developmental or social capital contributions to a child. Rather it is viewed as child-minding, fulfilling a parental need and not a child need. This is in direct contrast to the United States, where the hours out of school are recognised as a context for social, cognitive and physical development (Mahoney, Parente \& Zigler, 2010; Vandell \& Posner, 1999). Researchers, policy makers and governments in the US have become increasingly interested in how out-of-school time can be used as an opportunity for children and adolescents to learn and develop competencies (Mahoney, Vandell, Simpkins \& Zarrett, 2009). The SAC My Time Our Place: Framework for School Age Care in Australia (DEEWR, 2011) recognises the capacity of and advocates SAC to nurture children's well-being and competencies. Community perceptions have yet to catch up to this vision of SAC.

SAC settings are important contexts of childhood constituting the main locations outside of school where children play and socialise together (Bell, 2013). SAC enables contexts for friendships to develop. This is important as making friends relies on context rather than children's individual skills and personality (Peters, 2003). Friendships give children the opportunity to practise and enhance their social, emotional, communication and language skills through their engagement in conversations, cooperative and pretend play, conflict, and the sharing of feelings and experiences (Dunn, Cutting \& Fisher, 2002; Newcomb \& Bagwell, 1996).

SAC also protects and promotes children's play by affording children time, space and resources to play. This is important given that the time children spend playing has decreased considerably over the last two and a half decades. The reasons for this decline include more time spent on screen entertainment; competing extra-curricular activities; parental fears about children's safety; parents' lack of awareness about the benefits of unstructured activity and play and the shortage of quality play 
spaces near children's homes (Singer, Singer, D'Agostino \& DeLong, 2008; Witherspoon \& Manning, 2012). Play is critical to nurturing children's wellbeing and resilience (Lester \& Russell, 2008). Play is acknowledged to foster children's social, emotional, cognitive, physical development (Ginsburg, 2007; Singer et al, 2008) as well as affording children opportunities to learn about themselves, the world around them, life skills, creativity and imagination (Witherspoon \& Manning, 2012). My Time, Our Place recognises the roles of play in children's well-being, learning and development (DEEWR, 2011) and is guided by the principles laid out in the United Nations Convention on the Rights of the Child (1989) where all children have the right to relax and play, and to join in a wide range of cultural, artistic and other recreational activities. Again community perceptions have yet to catch up to the Framework in regarding SAC as a play safe haven and play as essential to children's optimal development.

Our study supports a central tenant of the framework, which is the need for children to be able to make choices and become involved in problem solving and decision making while contributing to their SAC community. The study aligns with other social research that includes children's voices to gain "richer, first-hand data from children's experiences and perspectives" (Tay-Lim \& Lim, 2013, p. 66). It also reflects MacNaughton, Smith and Davis (2007) reference to the United Nations Convention on the Rights of the Child (1989) that states that children have the right to express their views on all matters affecting them and for their views to be taken seriously (Article 12). The United Nations General Comment (No. 7) on Implementing child rights in early childhood further asserts that young children's right to express their views and feelings should be taken into account in "the development of policies and services, including through research and consultations" (Office of the High Commissioner of Human Rights, 2005, p. 7). Our research investigates children's experiences and perceptions of afterschool care with the intention of their responses adding to the literature, as well as bringing about change to current practices to better suit their wants and needs in SAC.

In Australia there has been scant research exploring children's perceptions of SAC. In an early study (Elliot, 1998) children asked about their perceptions of programming during one-on-one interviews, while mother's were asked about perceived benefits and program quality through a written survey. Elliot found that both children and parents had positive experiences with afterschool care but that it was a necessity rather than an optional activity. Younger children were more satisfied with afterschool care, while older children would have preferred more time at home to watch television and play with friends. In England however, there is a small body of literature about children's perceptions. The English government commissioned a range of research projects about SAC services. In particular, The impact of out of school care: A qualitative study examining the views of children, families and playworkers, (Barker, Smith, Morrow, Weller, Hey \& Harwin, 2003) investigated the perspectives of parents, staff and children utilising school age child care. Key findings included increased opportunities to play and develop friendships, as well as increasing children's self-confidence and social skills through social interactions and new activities. In their review of the literature Barker and colleagues cite other English research where children had named spending time with friends, activities 
both indoor and outdoor and excursions as positive outcomes of attending afterschool care.

\section{Research Question}

We asked the question What are children's experiences and perceptions of afterschool care? The research was exploratory, as only one other early study has examined children's experiences (Elliot, 1998) in Australia. The variables we examined were location (different states), age (younger 5-8 years and older 9-12 years), gender and attendance patterns (full-time versus part-time). As an exploratory study no hypotheses were put forward beyond expecting age differences based on Elliot's study. We did however; expect common themes of play and friends to be present in children's responses based on findings from the English study (Barker, 2003). We also anticipated great diversity in children's perceptions based on Bronfenbrenner's theories $(1979,1995)$. Just as no two children's development is the same, we expected children's experiences and perceptions of their experiences to be different from each other.

\section{$4 \quad$ Method}

\subsection{Research Sites}

Two diverse sites were used to better generalise findings. Canberra is the nation's capital city and is located in the Australian Capital Territory, with a population of 368,000 . Canberra has a low unemployment rate of $3.6 \%$. Nearly two thirds of the population (64.5\%) above 15 years has a post school qualification and $44.3 \%$ of the working population is employed as managers or professionals. In contrast, Logan is situated between Brisbane and the Gold Coast in Queensland with a population of 48,000 people. Logan has a high unemployment rate of $6.2 \%$. Nearly half of the population (48.6\%) above 15 years have a post school qualification and only $19.5 \%$ of the working population are employed as managers or professionals (ABS, 2013).

Convenience sampling was used, however, the six services in Canberra and eight services in Logan (total of 14 services) represented the three school sectors and a variety of service providers. In total there were seven government schools, three Catholic schools and four independent schools. The service providers included community service organisations and two schools. 


\subsection{Sample}

A total of 164 children participated in the study. There were slightly more males 88 $(53.7 \%)$ than females. Table 1 details the number and percentage of children in each year level. Nearly $60 \%$ of the children attended afterschool care in the ACT compared to $40.9 \%$ in Queensland. The proportion of children who attended afterschool care everyday or full-time compared to part-time was just over half $(51.9 \%, \mathrm{n}=84)$.

Table 1. Frequency distribution of number of children according to year level

\begin{tabular}{lcc}
\hline Year level & $\mathrm{N}$ & $\%$ \\
\hline Kindergarten & 23 & 14.0 \\
1 & 26 & 15.9 \\
2 & 27 & 16.5 \\
3 & 27 & 16.5 \\
4 & 34 & 20.7 \\
5 & 16 & 9.8 \\
6 & 9 & 5.5 \\
7 & 2 & 1.2 \\
Total & 164 & 100.0 \\
\hline
\end{tabular}

\subsection{Materials}

Five survey questions were used for this study. The questions were adapted from the English study, The impact of out of school care: A qualitative study examining the views of children, families and playworkers (Barker et al, 2003). We chose questions from their children's group discussion interview schedule including experiences "What is the best thing about afterschool care?", quality "How could we make afterschool care better?", social skills and friendships "Have you made any new friends at afterschool care?" and new opportunities "Is there anything you get to do at afterschool care that you don't get to do anywhere else?" We decided to also ask children "What is the worst thing about afterschool care?" to allow them to voice things they were not happy or satisfied with. A single A4 page was used to survey the children. The page was divided into six parts - one line down the middle of the page with three sections on each side. The questions were written at the top of each box with space below for children's written or pictorial responses.

\subsection{Procedure}

Ethics approval was granted by the University of Canberra. Six services were approached to join the study in Canberra and all agreed to be part of the study. In Logan, seventeen services were approached and ten agreed to be part of the research.

The researchers visited the SAC services and told the children about the study and how they could participate by answering questions through drawing, writing or 
telling the researcher. During the afternoon the researcher approached children individually and/or in groups. The majority of the children chose to answer the questions by telling the researcher who wrote down their answers. The researcher read out loud the responses of those children who drew or wrote their answers to check the researcher understood.

\subsection{Data analysis}

A thematic approach was used to analyse the data. That is, key themes emerged from the data and served as analytical categories (Fereday \& Muir-Cochrane, 2006). Processes were multi-iterative and non-linear, involving Cresswell's (2009) strategies of organising data, reading through data, beginning coding, generating categories and/ or themes based on coding, deciding how themes will be presented and interpreting the data. The analysis of data engendered two broad organising themes:

i. Developmental opportunities afforded by afterschool care

ii. Ways to move afterschool care services forward and further enhance developmental opportunities

We decided to use the National Quality Standard, a central component of the National Quality Framework that sets a national benchmark for early childhood care and education and SAC (Australian Children's Education and Care Quality Authority, 2014) to code responses in the second area of moving afterschool care forward. The National Quality Standard has established quality areas and was intended to promote continuous improvement by early childhood and SAC services. It is linked to My Time Our Place framework and was designed to provide accountability and transparency. Services are rated on seven quality areas comprising

1. Educational program and practice

2. Children's health and safety

3. Physical environment

4. Staffing arrangements

5. Relationships with children

6. Collaborative partnerships with families and communities

7. Leadership and service management

The last two quality areas were not deemed relevant to children's responses. We decided to use Relationships with children to code children's relationships with other children and Staffing arrangements to code children's relationships with staff.

The Statistics Program for Social Sciences (SPSS) version 22 was used to analyse the data. Inferential statistics (Mann-Whitney tests) were used to analyse differences between gender, age, state and attendance patterns where numbers were large $(n=>40)$. 


\section{Results}

\subsection{Wellbeing and Developmental Opportunities for Children Afforded by Afterschool Care}

Children's responses to what is the best thing about afterschool care and is there anything that you only get to do at afterschool care focused on holistic developmental opportunities afforded by afterschool. More than half the children surveyed in the study nominated activities as the best thing about afterschool care $(52.4 \%)$. Activities were those things planned by staff for children to do during the afternoon. Approximately one third of the children reported play as the best thing (34.1\%). Play was considered separate from activities based on the definition of play being unstructured and child initiated. Games included both board games and physical games. Games were considered different from play due to the presence of predetermined rules. While it is possible that children included play, games or craft as activities there were enough of the different responses to separate them. Table 2 details children's responses for the best thing about afterschool care. Responses that were categorised as "Other" included staff members, helping out, getting lollies, not having siblings around and the quiet area and the senior's room (a designated area for older children only). Such responses generally occurred once and consequently were grouped together.

Table 2. Frequency distribution of children's responses to "What is the best thing about afterschool care?"

\begin{tabular}{|c|c|c|}
\hline Children's responses & $\mathrm{N}$ & $\%$ \\
\hline Activities & 86 & 52.4 \\
\hline Play & 56 & 34.1 \\
\hline Other & 35 & 21.3 \\
\hline Friends & 31 & 18.9 \\
\hline Craft & 27 & 16.5 \\
\hline Games & 24 & 14.6 \\
\hline Computers & 19 & 11.6 \\
\hline Sports & 13 & 7.9 \\
\hline
\end{tabular}

* Percentages total more than 100 as children could give multiple answers

There was a statistical significant difference at a 0.05 level in children reporting activities according to where they lived. Children in the ACT (Mean Rank $=103.75$, $\mathrm{n}=97$ ) were significantly more likely to nominate activities than children from Queensland (Mean Rank $=51.74, \mathrm{n}=67)(\mathrm{U}=10063.5, \mathrm{z}=-7.970, \mathrm{pa}=.000$, two tailed). The effect can be considered large $(\mathrm{r}=-0.62)$ (Cohen, 1988). There were no differences according to gender, age or attendance patterns. There were no differences between children's responses about play according to any of the variables.

The majority of children reported that afterschool care afforded them opportunities that were unavailable to them anywhere else (84.1\%). The most commonly reported 
activity was games with $21.2 \%$ nominating them. The opportunity to play with friends was reported by $14.7 \%$ of the children. Responses that were coded as "other" included feeding the chickens, dramatic play, science activities, magic and digging for dinosaurs (in the sandpit). Table 3 details the frequencies of the children's responses.

Table 3. Frequency distribution of children's responses to "Are there any activities that you do here that you don't get to do anywhere else?"

\begin{tabular}{llc}
\hline Children's responses & $\mathrm{n}$ & $\%$ \\
\hline Games & 36 & 21.2 \\
\hline Other & 28 & 16.5 \\
Nothing & 27 & 15.9 \\
Friends & 25 & 14.7 \\
Play & 15 & 8.8 \\
Craft & 12 & 7.1 \\
Computers & 11 & 6.5 \\
\hline
\end{tabular}

As mentioned previously, making new friends is a developmental opportunity afforded by afterschool care. Nearly half the children (43.9\%) had made new friends. There were no significant differences between children's responses according to age or older or attendance patterns. There were however significant differences children's responses according to gender and where children lived. Mann-Whitney U tests showed girls (Mean Rank $=89.32, \mathrm{n}=76$ ) were significantly more likely to report having made friends at afterschool care than boys (Mean Rank $=76.32, \mathrm{n}=76$ ) $(\mathrm{U}=2800.000, \mathrm{z}=-2.087, \mathrm{p}=.037$, two tailed). This is a small effect size $(\mathrm{r}=-.16)$. Children from Queensland (Mean Rank $=107.69, \mathrm{n}=67$ ) were also more likely to report making new friends than children from the ACT $($ Mean Rank $=65.10, n=97)$ $(\mathrm{U}=1561.5, \mathrm{z}=-6.569, \mathrm{p}=.000$, two tailed $)$. This is a large effect size $(\mathrm{r}=-.51)$. The findings are interpreted in the discussion section.

\subsection{Ways to Move Afterschool Care Services Forward and Further Enhance Developmental Opportunities}

While afterschool care affords children multiple developmental opportunities, there are still ways in which services can move forward and further enhance children's opportunity for learning and development. The great majority of children had definite ideas on what was wrong with afterschool care and how it could be improved. Only $18.3 \%$ of children thought there was nothing that could be improved at afterschool care.

As noted in the methodology, the National Quality Standards were used to analyse children's responses related to service improvement. Children's responses about activities were coded as Programming. Responses about food, eating procedures, general rules and routines comprising group time were coded as Health and Safety. Group time is when children come from school and are expected to sit and wait for other children to arrive and then be told the activities and menu for the afternoon. Responses related to the afterschool care service equipment, resources and space 
were coded as Physical environment. As mentioned in the methodology children's relationships with other children were coded as Relationships with children, while children's relationships with staff were coded as Staffing.

Programming was the area children most frequently nominated as the worst thing about afterschool care $(28.7 \%)$. Nothing was the next most frequently reported response (23.2\%) followed by Health and Safety (19.5\%) and Physical Environment $(15.9 \%)$. Table 4 shows the frequencies of children's responses according to the different quality areas.

Table 4. Frequency distribution of children's responses to Question "What is the worst thing about afterschool care?"

\begin{tabular}{lcc}
\hline Children's responses & N & $\%$ \\
\hline Programming & 47 & 28.7 \\
\hline Nothing & 38 & 23.2 \\
Health and safety & 32 & 19.5 \\
Physical environment & 26 & 15.9 \\
Relationships with children & 25 & 15.2 \\
Staffing & 22 & 13.4 \\
\hline
\end{tabular}

There were no differences in children's responses of programming according to gender, age, state or attendance patterns.

Responses coded as Health and Safety were the most frequent reported as ways afterschool care could be improved (29.3\%). This was followed by Staffing $(25 \%)$ and Nothing (18.3\%). Table 5 details children's responses to how afterschool care could be improved.

Table 5. Frequency distribution of children's responses to Question "How could we make afterschool care better?"

\begin{tabular}{lcc}
\hline Children's responses & N & $\%$ \\
\hline Health and safety & 48 & 29.3 \\
Staffing & 41 & 25.0 \\
\hline Nothing & 30 & 18.3 \\
Relationships with children & 29 & 17.7 \\
Programming & 26 & 15.9 \\
Physical environment & 17 & 10.4 \\
\hline
\end{tabular}

There were no significant differences between children's responses of Health and Safety according to gender, age or state. There was a difference according to attendance patterns with children who attended part-time (Mean Rank $=90.73, \mathrm{n}=78)$ more likely to report Health and Safety than children who attended full (Mean Rank $=72.93, \mathrm{n}=84)(\mathrm{U}=2556.000, \mathrm{z}=-3.052, \mathrm{p}=.002$, two tailed $)$. This is a small effect size $(\mathrm{r}=-.24)$.

There were no significant differences between children's responses of Staffing according to gender, age or attendance patterns. There was a difference according to state with children from Queensland (Mean Rank $=100.01, \mathrm{n}=67$ ) more likely to report Staffing than children from the ACT (Mean Rank $=70.40,67)(U=2076.000$, $\mathrm{z}=-5.229, \mathrm{p}=.000$, two tailed). This is a medium effect size $(\mathrm{r}=-.41)$. 


\section{Discussion}

The children who participated in the survey were very willing to share their ideas about afterschool care. Their responses were well considered and their suggestions for improving afterschool care were for the most part actionable. The children appeared gratified to have someone ask their opinions. Perhaps the most important finding was that children did not consider SAC a filler activity between school and home or somewhere they were "cared for." Children regarded SAC as a time and place for playing, making friends and doing activities. Their responses show SAC as a context for development where they were building skills and competencies.

Based on Bronfenbrenner's theory of development $(1979,1995)$ we expected children's responses to the survey questions to be diverse. The responses reflected the different lives, relationships, experiences and interests of the children. Despite these differences there were common themes emerging particularly play, friendship, craft, screen time and games suggesting that there are commonalities in children's experiences of afterschool care in Australia and some generalisations could be made from the findings.

More than half of the children reported activities as the best thing about afterschool care. This is not surprising as services program a variety of activities everyday for the children to engage with. Usually services try to vary the types of activities over time. Activities could include many of the categories we used to analyse the data (craft, games, computers, sports). This may account for more children in the ACT responding this way. In Queensland children may have specified exactly what activities they enjoyed while in Canberra their response was more generalised. It seems unlikely that Canberra services offer better or different activities than Queensland services. Our finding aligns with the English study results where children and their parents reported that children enjoyed experiencing new activities at SAC (Barker et al, 2003). Greater discussion of the types of activities follows the section on play.

Play was the second most common response children gave when asked What is the best thing about afterschool care? SAC both promotes and protects children's play. Children can engage in play every day at afterschool care. The only interruption to their play is group time and eating where children are required to come together as a group. Services offer a range of toys, outside equipment and other resources for play that may not be available to children in their homes. Children can engage in longer periods of play than is offered at school during lunch breaks and they have variety of peers to play with who may or may not be the same age. Our finding resonates with results from the English study (Barker et al, 2003). According to Barker and colleagues, SAC provides dedicated and uninterrupted play spaces for children with time and resources for play often more plentiful than those available at home or school. Provision of play opportunities is critical to the overall wellbeing of children.

Craft, friends and games were the next most popular responses given by children as the best thing about afterschool care. In general, craft activities are offered everyday at all afterschool care services. Over time children can experience a wide range of artistic pursuits and craft activities that may not be available anywhere else. For 
example most homes do not have clay and finger knitting materials. Children may have some opportunity to engage in these activities at school but they would not be offered as often as they are at afterschool care. The combination of a crowded curriculum and priority given to literacy and numeracy, means there is limited time for art in primary schools (Power \& Klopper, 2011).

Just as afterschool protects and promotes play, it also supports and enables children's friendships. Afterschool care allows children to socialise with children outside of school and of all different ages, something that may not occur in schools where children in different year levels are assigned different play areas. Approximately 20 percent of children reported friends as the best thing about afterschool care while $44 \%$ said they had made new friends at afterschool care. This finding corresponds with results from the National English SAC study where one of the most significant impacts of SAC was that children were able to spend more time with existing friends and $85 \%$ of parents reported that the afterschool care club enabled their children to make new friends (Barker et al, 2003). The finding that more girls than boys reported making new friends is supported by the literature. In their review of sex differences in peer relationship processes, Rose and Rudolph (2006) report that boys are more likely to play in large groups and have integrated social networks than girls. In the context of afterschool care boys are more likely to already know each other through playing in large groups and their friends are more likely to be friends with one another. Similarly, that more children in Logan reported making new friends than children in Canberra can be explained by the size of the schools in each location. Schools in Queensland are much larger than schools in the Australian Capital Territory. The likelihood of Queensland children knowing all the children in their year level or school is much smaller than children in the ACT.

Many children reported games as the best thing about afterschool care. Board games are standard resources in many afterschool care services. Board games are well suited to afterschool care. Children can play games with a variety of peers and educators rather than just parents or siblings who may not always have time or the inclination to play (think monopoly). There is a wider choice of games than maybe available in home environments. Likewise, afterschool care services generally play games everyday. Again children have the opportunity to play these games with a large group of peers and educators.

Over $10 \%$ of children reported computers as the best thing about afterschool care. In most instances children use the school computer labs to play on the computers. This means large numbers of children can play at one time and they can interact with each other while playing. This is different from playing computers at home where children usually play alone or perhaps with one other person (Orr Vered, 2006).

A small number of children named sport as the best thing about afterschool care. While the numbers were too small to carry out any statistical analyses there may have been differences in children's responses according to where they lived. Children in the ACT also have the highest rates of participation in an organised sport in Australia at $73 \%$ while Queensland has the second lowest rate in the country with 57\% (ABS, 2012). The Department of Education in Queensland has given priority to literacy and numeracy in Queensland schools resulting in fewer opportunities for 
games and sports in schools (Department of Education, Training and Employment, Queensland, 2014).

Interestingly there were variations in what children perceived as the worst thing about afterschool care and how afterschool care could be improved. It would be reasonable to assume that children's responses would align, that is what they most dislike about afterschool care, they would want to change. However, this was not the case. Children perceived Programming, Health and Safety and Physical Environment as the worst things about afterschool care but would like to change areas of Health and Safety, Staffing and Relationships with children.

These findings suggest that children are pragmatic. Whether intentional or not they have nominated areas for improvement that can be changed. Children realise that it is more difficult to change the physical environment but see that food, rules and people (both staff and other children) could change. Anecdotally fewer than 5 children asked for things like painting the centre a rainbow or having pony rides or bringing their pets to afterschool care as ways of making afterschool care better. Children's responses were reasonable and more importantly actionable by staff. There was a difference in who reported Health and Safety as a way to improve afterschool care. Children who attended part-time suggested more often Health and Safety than children who attended every day. It may be that children who attend everyday are so used to the rules and routines that they don't think to question them or see alternatives.

Similarly interesting was that activities were reported as the best thing about afterschool care, yet they were also the worst thing, as activities constitute the main component of programming. A possible explanation is that children like activities but sometimes the activities on offer are not ones they like or think are appropriate. For example, children commented that "the games in the hall were for boys" or that "there isn't enough boy's toys" when reporting the worst thing about afterschool care. This explains why they nominated activities as the worst thing but did not nominate them in the same way as to how afterschool care could be improved. Children may accept that activities may not always be to their liking and that many children's wishes need to be accommodated.

\subsection{Moving Forward}

Children nominated Health and Safety as the number one thing that would improve afterschool care. Health and Safety was also rated as the second worst thing about afterschool care. It was the only quality area that appeared in the top three for both categories. Clearly this is an area that services could review. Services could question whether all the rules and procedures are absolutely necessary or appropriate? Certainly, there is no real need for group time. Children have already spent the day at school sitting and listening. There are better ways for children to sign in and go out to play. They can see the activities on offer and if they want to know what will be on offer for afternoon tea, they can look or ask a staff member. While many children are fussy eaters, services could ask children and parents what foods they could serve. Our results show that children are able to give sensible suggestions. In terms 
of safety rules, staff could shift to risk-benefit rather than risk-aversion. The benefits of practicing cartwheels on the grass under supervision far outweigh the very small risk that they will break their arm.

Similarly staff may need to look at themselves and how they interact with children. Nearly $14 \%$ of children reported staff as the worst thing about afterschool care ( $5^{\text {th }}$ on list) and a quarter of the children named staff as how afterschool care could be improved $\left(2^{\text {nd }}\right.$ on list). These numbers are more than just a few disgruntled children who are not allowed to do as they please.

The high number (15.2\%) of students reporting other children as the worst thing is concerning. This response may simply refer to children having to interact with children they do not like or who they perceive as "mean." It is possible that sometimes children are not included in games and activities that they would like to be included in. Social skills training may be needed in some services so that children can develop better social skills enabling them to have more positive interactions with their peers. Lack of good role modelling or failing to intervene or support children in building or repairing peer relationships by staff can also undermine children's social skills or escalate problems.

These three areas (Health and Safety, Staffing and Relationships with children) are affected by the skill or quality of staff members. The low skill-low pay cycle and limited working hours mean that services are not always able to recruit staff members with the desired skill set of working with children. Only the educational leader (coordinator or supervisor) is required to have a qualification in working in SAC. Educators (carers or people working on the floor) are not required to have any qualifications. Professional development of staff in the areas of Health and Safety and relationships with children would benefit staff personally and improve children's satisfaction of afterschool care.

\subsection{Limitations and Future Directions}

As with any study there were limitations. The response rate across all services was low. As a result it is possible that the sample was biased. It is worth noting that some of the services in Canberra requested that we survey all the children to help them improve their service. We did not include this data in our study; however, it was not statistically different from the study data. This suggests that our results may be generalisable. The services in our sample were not totally representative of the sector. While the services were located across the three school systems, the majority of service providers were not-for-profit community organisations. We did not have any for-profit service providers or services that were not located at schools. Similarly, the services were both located in cities. Different results may have been found in regional and remote areas where there may be fewer recreational opportunities. Finally, we were not able to compare our findings with the National Quality Standard assessments from the Australian Children's Education and Care Quality Authority. The majority of the services were yet to undertake their assessment. It would be interesting to see if children's perceptions matched those of adult assessors. 
Further research is required to explore whether our results are reflective of children's experiences and perceptions of SAC across Australia. The differences according to where children lived were somewhat unexpected and it would be interesting to discover whether further differences exist across other states and territories. Future studies should include services located in remote and regional centres, services located in very high and low socio-economic status areas and the full range of service providers including for-profit and child-care centres. Developmental outcomes of attending SAC also should be explored. Only two Australian studies have investigated developmental outcome of attending SAC. Given the large numbers of children attending SAC, comprehensive data should be available to parents and policy makers alike.

The hours after school are an important context for development and as such SAC should not be dismissed as a filler between school and home. The time children spend in SAC across the weeks, months and years contribute to their well-being and shape their physical, social, emotional and cognitive development. It is time for parents and community perceptions to shift. Rather than a service for parents that provides care for children in a safe environment, SAC should be viewed as an opportunity where children can develop and learn new skills and competences, establish and maintain relationships with peers and adults and generate a sense of belonging and well-being. SAC deserves that same status given to other forms of children's services such as early childhood education and care and school given how it contributes to children's holistic development. Children as stakeholders have pragmatic ideas how to enhance the quality of the experiences at afterschool. For services to further improve, it is important for them to engage with children and heed their insights.

\section{References}

Arnold, V. (2002). Times, they are a changin'? yes, and are they changin'! Paper presented at the 2002 Queensland Children's Activities Network State Conference Brisbane, Queensland.

Australian Bureau of Statistics (ABS) (2011). Household Use of Information Technology, Australia, 2010-11-Cat8146.0. Retrieved 18December, 2013 fromhttp://www.abs.gov. au/AUSSTATS/abs@.nsf/Latestproducts/8146.0Media\%20Release12010-11?opendocument\&tabname $=$ Summary \&prodno $=8146.0 \&$ issue $=2010-11 \&$ num $=\& v i e w=$

Australian Bureau of Statistics (ABS) (2012). Children's Participation in Cultural and Leisure Activities, Australia, April 2012 - Cat 4901.0. Retrieved 16 December, 2013 from http://www.abs.gov.au/ausstats/abs@.nsf/Latestproducts/4901. 0Main\%20Features5Apr\%202012?opendocument\&tabname=Summary\&prodno $=4901.0 \&$ issue $=A$ pr\%202012\&num $=\&$ view $=$

Australian Bureau of Statistics (ABS) (2013). Quick Stats. Retrieved 15 December, 2013 from http://www.abs.gov.au/websitedbs/censushome.nsf/home/quickstats?opendocument\&navpos $=220$ 
Australian Children's Education and Care Quality Authority (2014).National Quality Framework. Retrieved 10 June, 2014 from http://acecqa.gov.au/national-quality-framework

Barker, J., F. Smith, V. Morrow, S. Weller, V. Hey, \& J. Harwin (2003). The Impact of Out-of-School Care: A Qualitative Study Examining the Views of Children, Parents and Playworkers. DfES Research Report 447. London: The Stationery Office.

Bell, K. (2013). What is the experience of play for children in one school age care service? Unpublished honours dissertation, Brisbane, Queensland: Griffith University.

Brennan, D. (1994). The politics of Australian child care: From philanthropy to feminism. Melbourne, Australia: Cambridge University Press.

Brennan, D. (1996). Outside school hours care: a review of the Australian and international literature: Prepared for the Department of Health and Human Services (unpublished).

Brennan, D. (1999). Child care: Choice or charade. In L. Hancock (Ed.), Women, public policy and the state (pp. 85-98). Melbourne, Australia: Macmillan.

Bronfenbrenner, U. (1979). The ecology of human development. Cambridge, Massachusetts: Harvard University Press.

Bronfenbrenner, U. (Ed.) (1995). The bioecological model from a life course perspective: Reflections of a participant observer. Washington, DC: American Psychological Association.

Cartmel, J. (2007). Outside school hours care and schools. (Doctoral Dissertation). Faculty of Education, Queensland University of Technology. Retrieved from http://eprints.qut.edu.au/17810/1/Jennifer_Cartmel_Thesis.pdf

Cartmel, J., \& Grieshaber, S. (2014). Communicating for quality in school age care services. Australasian Journal of Early Childhood, 39(3), 23-28.

Cohen, J. (1988). Statistical power analysis for the behavioral sciences (2nd ed.). Hillsdale, NJ: Erlbaum.

Creswell, J. (2009). Research design: Qualitative, quantitative and mixed method approaches (3rd ed.). Thousand Oakes, CA: Sage Publications.

Department of Education, Employment and Workplace Relations (DEEWR). (2011). My Time Our Place: Framework for School Age Care in Australia. Canberra.

Department of Education, Employment and Workplace Relations (DEEWR). (2013). Child care update. August 2013. Retrieved from http://www.mychild.gov.au/ pages/ResourcesReports.aspx

Department of Education, Training and Employment, Queensland. (2014). P-12 curriculum, assessment and reporting framework: Recommended curriculum time allocations for Queensland state schools 2014-2016. Retrieved 2 January, 2014 from http://education.qld.gov.au/curriculum/framework/p-12/docs/time-allocations.pdf

Department of Family and Community Services (FaCS) (2005). Evaluation of the Outside school hours care quality assurance training project. Canberra: Australian Government. 
Department of Health \& Family Services (1997). Key findings on the national school age care pilot and research program. Canberra: Australian Government Publishing.

Dunn, J., Cutting, A. L., \& Fisher, N. (2002). Old friends, new friends: predictors of children's perspective on their friends at school. Child Development, 73(2), 621-635.

Elliot, A. (1998). Care programs for school age children in Australia. Childhood Education, 74(6), 387-392.

Fereday, J., \& Muir-Cochrane, E. (2006). Demonstrating rigor using thematic analysis: A hybrid approach of inductive and deductive coding and theme development. International Journal of Qualitative Methods, 5(1), 80-92.

Finlason, J. (2004). The Network: When dreams become reality. Sydney, NSW: Network of Community Activities.

Gammage, P. (2003). Outside school hours care: Does it matter? Paper presented at the Our Children the Future, Early Childhood Conference 3 - School Age Care Symposium. Retrieved May 42004 from http:/www.octf.sa.edu.au/ octf/a8_publish/modules/publish/content.asp?id=12346\&navgrp=141, Adelaide Convention Centre.

Ginsburg, K. R. (2007). The Importance of Play in Promoting Healthy Child Development and Maintaining Strong Parent-Child Bonds. Pediatrics, 119(1), $182-191$.

Hand. K., \& Baxter, J. A. (2013). Maternal employment and the care of school-aged children. Australian Journal of Labour Economics, 16(3), 329-349.

Lester, S., \& Russell, W. (2008). Play for a change: Play, policy and practice, a review of contemporary perspectives. UK: Gloucester University.

MacNaughton, G., Smith, K., \& Davis, K. (2007). Researching with children: The challenges and possibilities for building "child friendly" research. In A. Hatch (Ed.), Early childhood qualitative research (pp. 67-184). New York, NY: Routledge.

Mahoney, J. L., Parente, M. E., \& Zigler, E. F. (2010). After-school program participation and children's development. Invited chapter to appear in J. Meece \& J. S. Eccles (Eds.), Handbook of research on schools, schooling, and human development (pp. 379-397). New York, NY: Routledge.

Mahoney, J. L., Vandell, D. L., Simpkins, S. D., \& Zarrett, N. R. (2009). Adolescent out-of-school activities. In R. M. Lerner \& L. Steinberg (Eds.), Handbook of adolescent psychology: Contextual influences on adolescent development (3rd ed., Vol. 2, pp. 228-267). Hoboken, NJ: Wiley.

Moyle, H., Meyer, P., \& Evans, A. (1996). Outside school hours care services in Australia. Retrieved 20 October 2007, from http:/www.aihw.gov.au/publications/index.cfm/title/190

Mullan, K. (2012). School's out - After-school's. In: Children's after-school care arrangements and activities. The Longitudinal Study of Australian Children Annual statistical report 2012. Melbourne: Australian Institute of Family Studies

Newcomb, A. F., \& Bagwell, C. L. (1996). The developmental significance of children's friendship relations. In W. M. Bukowski, A. F. Newcomb \& W. W. Hart- 
up (Eds.), The company they keep: friendship in childhood and adolescence (pp. 289-321). Cambridge: Cambridge University Press.

OECD (2001). Starting strong: Early childhood education and care. Paris, France: Organisation for Economic Co-operation and Development.

Office of the High Commisioner of Human Rights (2005). General comment Number 7. Implementing child rights in early childhood. OHCHR.

Orr Vered, K. (2006). Children and media in out of school hours care: a Practical resource for service and program planning, The State of South Australia, Department of Education and Children' Services.

Palsdottir, K. (2012). Care, learning and leisure: The organsiational identity of asfter-school centres for six- to nine- year old children in Reykjavik. (Doctoral Dissertation) University of Iceland. Retreived from http://skemman. is/en/stream/get/1946/16754/38970/1/phd thesis_palsdottir.pdf;jsessionid $=8$ AED33A758AF8FFB5C86CD6FB93DD $\overline{8}$ FC

Peters, S. (2003). "I didn't expect that I would get tons of friends ... more each day": Children's experiences of friendship during the transition to school. Early Years, 23(1), 45-53.

Power, B., \& Klopper, C. (2011). The classroom practice of creative arts education in NSW primary schools: A descriptive account. International Journal of Education \& the Arts, 12(11), 1-27.

Rose, A. J., \& Rudolph, K. D. (2006). A Review of Sex Differences in Peer Relationship Processes: Potential Trade-offs for the Emotional and Behavioral Development of Girls and Boys. Psychological Bulletin,132(1), 98-131.

Simoncini, K., Caltabiano, N. \& Lasen, M. (2012). Children's behaviour and their care arrangements after school. Australasian Journal of Early Childhood, 37(1), $108-118$.

Singer, D. G., Singer, J. L, D'Agostino, H., \& DeLong, R. (2008). Children's Pastimes and Play in Sixteen Nations: Is Free-Play Declining? American Journal of Play, 1(3), 283-312.

Tay-Lim, J., \& Lim, S. (2013). Privileging Younger Children's Voices in Research: Use of Drawings and a Co-Construction Process. International Journal of Qualitative Methods, 12(1), 65-83.

United Nations Committee on the Rights of the Child (1989). Convention on the Rights of the Child. New York: United Nations.

Winefield, H., Piteo, A., Kettler, L., Roberts, R., Taylor, A., Tuckey, M., Denson, L., Thomas, K., \& Lamb, I. (2011). Australian parents' needs and expectations regarding out of school hours care: A pilot study. Journal of Early Childhood Research, 9(3), 196-206.

Witherspoon, L., \& Manning, J. P. (2012). Active Gaming: The Future of Play? American Journal of Play, 4(4), 464-487.

Vandell, D. L., \& Posner, J. K. (1999). Conceptualization and measurement of children's after-school environments. In S. L. Friedman \& T. D. Wachs (Eds.), Measuring Environment across the life span: Emerging methods and concepts (pp. 167-196). Washington D. C.: American Psychological Association. 